\title{
Rumen digestion and productivity of bulls when using linseed cake and choline
}

\author{
N.V. Bogolyubova ${ }^{1}$ and V.V. Zaitsev, ${ }^{2, *}$ \\ ${ }^{1}$ Federal Science Center for Animal Husbandry named after Academy Member L.K. Ernst, 142132 Dubrovitsy village, Podolsk, Moscow \\ region, Russia \\ ${ }^{2}$ Department of Bioecology and Physiology of Agricultural Animals, Samara State Agrarian University, 446442 Kinel, Samara region, \\ Russia
}

\begin{abstract}
We have studied the peculiarities of the processes of rumen digestion in bulls while feeding them linseed cake in combination with the "protected" form of choline. When linen cake and choline were included in the diet, the most favorable conditions for the development of microorganisms were created in the rumen of animals, which had an impact on the growth of live weight.
\end{abstract}

\section{Introduction}

Growing young animals in the conditions of intensive industrial animal husbandry as a complex of veterinary measures aimed at realizing the genetic properties of animals in the process of their growth and development, should include an increase in adaptive abilities and stress resistance based on the prevention of disorders of the morphofunctional systems of the body. For the formation of animals with high productivity, the development and application are relevant of methods of directed physiological correction of the digestive and metabolic processes occurring in the body of growing animals [1].

The fodder entering the ruminant rumen is exposed to rumen microflora. The complex stomach conditions in this chamber characterize it as an anaerobic system with strong restorative properties. In such an environment, a very specific population of microorganisms is developing, including a variety of anaerobic bacteria, fungi, and protozoa, whose continuous growth is ensured by the periodic intake of food eaten by animals into the rumen [2].

The formation and regulation of the quantitative and qualitative composition of the microbiocenosis of the gastrointestinal tract can accelerate the creation of an optimized type of digestion in growing animals, with an increase in the intake and digestibility of nutrients in the diet. In this regard, the use of useful symbiotic microflora regulators in the form of enzyme-probiotic preparations, which are an effective way of stimulating the development of the entire digestive system, is promising for calves [3-5].

In the rumen, microorganismenzymes meet up to $80 \%$ of energy demand, $30-50 \%$ in protein, largely in macroand micronutrients and vitamins, mainly group B. It digests 50 to $70 \%$ of raw fiber. There is a close relationship between the chemical composition and nutritional content of the feed substrate, the number of scar microorganisms and animal productivity. Substrates high in nitrogen, protein, fat, BEV have a greater stimulating effect on the growth and reproduction of the microflora of scar compared to substrates with less content of these nutrients.

The substrate composition of the diet also has an impact on the scar environment. Optimal for the reproduction of scar microorganisms forage substrate is characterized by a acesic acid type of fermentation and the $\mathrm{pH}$ of the environment closer to neutral - from 6.6 to 6.9. Less optimal feed substrate is characterized by propio-oil type of fermentation and more acidic $\mathrm{pH}$ of environment from 6.2 to 6.5. Thus inflow of saliva, advancement of food masses on an digestive tract and absorption of final products of an exchange of microorganisms through a wall of a scar in blood support in it necessary conditions for their growth.

One of the tasks in ruminant nutrition is to provide optimal living conditions for microorganisms that inhabit the gastrointestinal tract, in particular the rumen. This determines the efficiency of the use of nutrients in feed rations, as well as the provision of the body in essential amino acids, vitamins, the producers of which are symbiotic microflora [6-8].

One of the ways to strengthen the fodder base of agricultural enterprises is to increase the sowing and yield of high-protein and oilseeds. Currently, the oil extraction plants in Russia mainly process sunflower, the meal and meal of which occupy about $60 \%$ of the total production of plant sources of feed protein. With the development of flax farming, the possibilities of using flaxseed, which have dietary value and close to the rich amino acid composition of sunflower, with high content of lysine,

* Corresponding author: Zaycev_vv1964@mail.ru 
methionine, leucin, with a high digestibility of protein. Flax is the source of most vitamins - B1, B2, B6, niacin, pantothenic acid, folic acid, biotin, tocopherols (vitamin E). The content of thiain (vitamin B1) and folic acid is especially high. Flax contains a number of macro and micronutrients.

The highest content of flax, phosphorus and magnesium is highest in flax seeds. Fats that remain in flaxseed oil after the oil is distilled have all the beneficial properties, as well as flaxseed oil. Flaxseed oil in the content of unsaturated fatty acids exceeds fish oil by 2 times. Flax cake is widely used for feed purposes, which due to the high content of mucous substances is also of dietary importance, and proteins, which are part of it, have high value.

Because of the record content of flax cake lignans, flax cake has gained a reputation as the natural strongest growth stimulator in young animals. In addition, flax cake is a source of most vitamins, macro- and microelements $[9,10]$. The positive influence of the inclusion of flax cake on the digestive processes in ruminants has been established. [11].

Table 1. Feeding diet of bulls

\begin{tabular}{|l|c|c|}
\hline Feed & Control & $\begin{array}{l}\text { Experimenta } \\
\text { Hay }\end{array}$ \\
\hline $\begin{array}{l}\text { legumes, kg } \\
\text { Concentrates, kg }\end{array}$ & 4.0 & 4.0 \\
\hline "Protected" choline, kg & - & 6.0 \\
\hline Salt-lyse & + & 0.01 \\
\hline \multicolumn{2}{|c|}{ Concentrate composition, \% by nutritional value } \\
\hline Barley & 60 & 45 \\
\hline Wheat & 30 & 20 \\
\hline Oats & 10 & 20 \\
\hline Flax-burnt & - & 15 \\
\hline \multicolumn{2}{|c|}{ The diet contains } \\
\hline Exchange Energy, MJ & 88.7 & 88.88 \\
\hline Dry substance, g & 8700 & 8745 \\
\hline Raw protein, g & 1076 & 1215 \\
\hline Raw fat, g & 243.2 & 327.2 \\
\hline Raw fiber, g & 1476 & 1562 \\
\hline Calcium, g & 38.2 & 39.0 \\
\hline Phosphorus, g & 21.2 & 24.0 \\
\hline
\end{tabular}

Thus, when feeding flaxseed to live animals, an increase in the formation of volatile fatty acids in the rumen is established to $15 \%$, a higher level of formation of symbiont microflora, mainly due to bacterial mass. Methyl-containing compounds (methionine, cystine, choline, carnitine) play an important role in the reactions of permethylation, as a result of which choline phosphatides are synthesized, forming cell membranes, as well as substances involved in ensuring their permeability and other physiologically active compounds that play a huge role in the metabolic processes and maintaining homeostasis of the body. One of the sources of methyl groups and the most important metabolite is choline (trimethylethanolamine, vitamin B4) [12].
The task of our experiment was to study the processes of rumen digestion in bulls while feeding them linseed cake in combination with the "protected" form of choline.

\section{Materials and methods of the study}

The studies were carried out in the physiological yard of the Ernst VISH FGBNU in 2 groups of bulls on the fattening of black-motley Holsteinized breed. Animals were divided into 2 groups (control and experimental) of 7 heads each according to the principle of analogues.

The ration of the control group consisted of hay of cereals and legumes and concentrates, which included barley (60\% nutritious), wheat $(30 \%)$ and oatmeal $(10 \%)$ dyeing. The diet of the experimental animals differed by the fact that linseed cake was introduced into the concentrate. Concentrates included barley $(45 \%)$, wheat $(20 \%)$, oatmeal $(20 \%)$ and flax cake $(15 \%)$. In addition to the main diet, the experimental group of bulls received 10 $\mathrm{g}$ of choline in the form "protected" from the indirect action of the rumen microflora (Table 1.).

Animal diets were balanced in terms of basic nutrients and energy and contained $8.5 \mathrm{k}$.e.g. and $85.40 \mathrm{~mJ}$ of metabolic energy. The duration of the experiment was 90 days. Live weight of bulls at the beginning of the experiment was $368 \mathrm{~kg}$. In the following methods of feeding: initial moisture (GOST R 54951), air-dry substance (GOST 31640-2012), protein content (GOST 32044).1-2012), fat (GOST 32905-2014), fiber (GOST ISO 6865-2015), BEV (calculated method), ash (GOST 32933-2014), gross energy, metabolic energy (calculated method), calcium (GOST 32904-2014), phosphorus (GOST R 51420-99).

The duration of the experience was 90 days. At the end of the experiment (in case of slaughter), samples of the scar content were taken, where the following methods were used to determine: $\mathrm{pH}$, the total amount of volatile fatty acids - by the steam distillation method in the Markham apparatus; concentration of ammoniacal nitrogen - by the microdiffusion method according to the Conway; amylolytic activity - by the photometric method; biomass of protozoa and bacteria - by the method of differentiated centrifugation. Live weight gains of experimental bulls were calculated on the basis of monthly weights.

\section{Results and discussion}

The optimum $\mathrm{pH}$ value in the rumen of cattle is from 6 to 6.5 units. In our experiment, the $\mathrm{pH}$ value of the rumen fluid of the experimental bulls, who received flax cake and choline in the diet, was 6.55 units, which is 0.09 less than in the control animals (Figure 1).

Changes in the $\mathrm{pH}$ of the rumen of experimental animals in the acidic direction is associated with more intensive fermentation in the rumen, which is confirmed by the data on the concentration of volatile fatty acids (VFAs) in the rumen fluid of the bulls who took with the feed linseed cake and choline (Figure 2). Volatile fatty acids are formed in the rumen mainly as a result of fermentation of feed carbohydrates and constitute the 
main source of energy for ruminants. Only a small fraction of the carbohydrates consumed with the feed avoids splitting in the rumen.

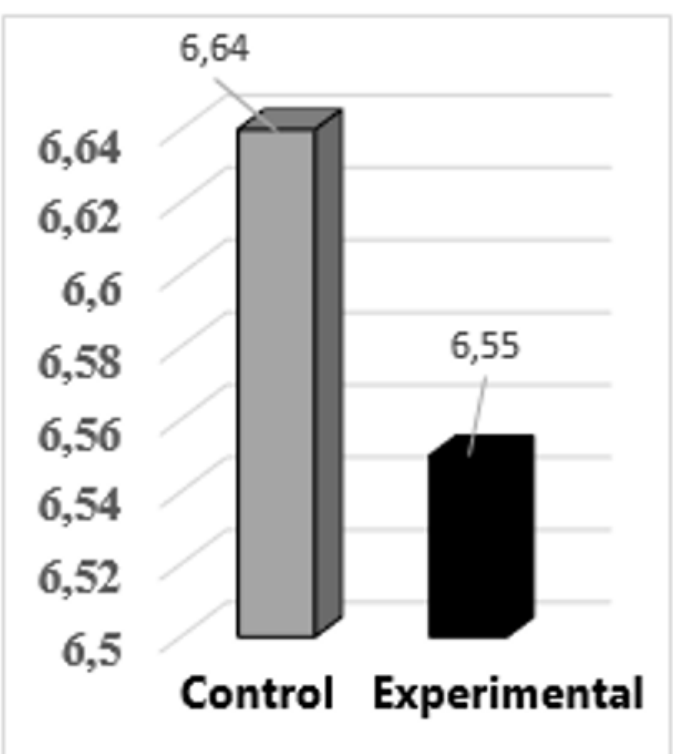

Fig. 1. $\mathrm{pH}$ of rumen content, experimental animals

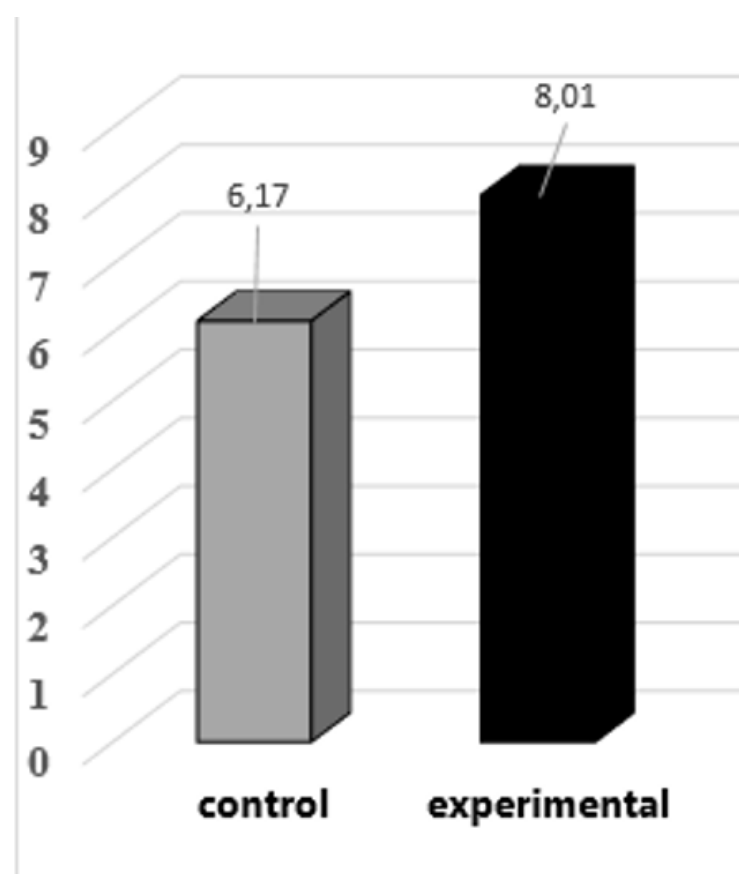

Fig. 2. Concentration of volatile fatty acids in test animals' rumen liquid, $\mathrm{mol} / 100 \mathrm{ml}$

In control animals, the concentration of LZK in the rumen fluid was $6.17 \mathrm{mMol} / 100 \mathrm{ml}$, which is $23 \%$ lower than in experimental animals with a reliable difference $(\mathrm{P}<0.05)$, which indicates a higher level of hydrolysis of carbohydrates in their pre-stomachs and is confirmed by previous studies.
Nitrogen metabolism in ruminants is another example of the effect of rumen microorganisms on host nutrition. The concentration of ammonia, the final metabolite of amino acids cleavage, in the rumen of animals that received flax cake and cholinese-soluble foods was 9.41 $\mathrm{mg}$, which is slightly higher than in control animals.

In experiments Poverinova E.M. [11] when feeding bulls on fattening rapeseed, linseed and redhead cake, higher digestibility coefficients and use of feed nutrients were observed. And in the early studies of FGBNU FSU Ernst VISH during feeding sheep flax cake noted a higher level of volatile fatty acids in the rumen, which may indicate a higher level of hydrolysis of carbohydrates in the pre-stomachs when using vegetable waste [13].

At the same time, a higher level of symbiotic microflora formation was revealed, mainly due to bacteria in the rumen content of the experimental group of sheep [14]. Similar results were obtained in our experience on fattening steers.

Data on the content of microbial mass in the rumen content of experimental animals are presented in Table 2.

Table 2. Content of microbial mass in the rumen content $(\mathrm{M} \pm \mathrm{m}, \mathrm{n}=3)$

\begin{tabular}{|c|c|c|c|}
\hline \multirow{2}{*}{ Group } & \multicolumn{3}{|c|}{ In $100 \mathrm{ml}$ of rumen content, $\mathrm{mg}$} \\
\cline { 2 - 4 } & bacteria & protozoa & total \\
\hline Control & $\begin{array}{c}387.0 \pm 14 \\
.9\end{array}$ & $271.2 \pm 31.5$ & $658.1 \pm 31.0$ \\
\hline $\begin{array}{c}\text { Experimen } \\
\text { tal }\end{array}$ & $\begin{array}{c}461.7 \pm 18 \\
.3^{*}\end{array}$ & $353.6 \pm 28.5$ & $\begin{array}{c}815.3 \pm 29.3 \\
*\end{array}$ \\
\hline
\end{tabular}

The difference is true for $\mathrm{P} ; *<0.05$

When feeding flax cake bulls in combination with choline in the "protected" form noted an increase in the content of both protozoa and bacteria in the rumen, and the total amount of symbiontic microflora. Thus, the content of bacteria in the rumen of experimental animals was $461.7 \mathrm{mg} / 100 \mathrm{ml}$, which is $19.3 \%$ higher $(\mathrm{P}<0.05)$ than in the control animals.

The difference in the simplest way between the control and experimental groups was $82.4 \mathrm{mg} / 100 \mathrm{ml}$, or $30.4 \%$ in favor of the experimental animals. Thus, when linseed cake and choline were included in the diet in the animals' rumen, the most favorable conditions for the development of microorganisms were created. The same tendency was obtained in the experiments of other researchers [15].

Changes in the composition of the diet are reflected in the productivity of steers (Figure 3 ).

Thus, the bulls of the experimental group were observed to have increased live weight growth. Average daily increase for the period of the experiment in experimental bulls was $904.8 \mathrm{~g}$, which is $9.7 \%$ higher than in control animals (Table 3 ).

Our data are consistent with the data of other researchers [8]. 


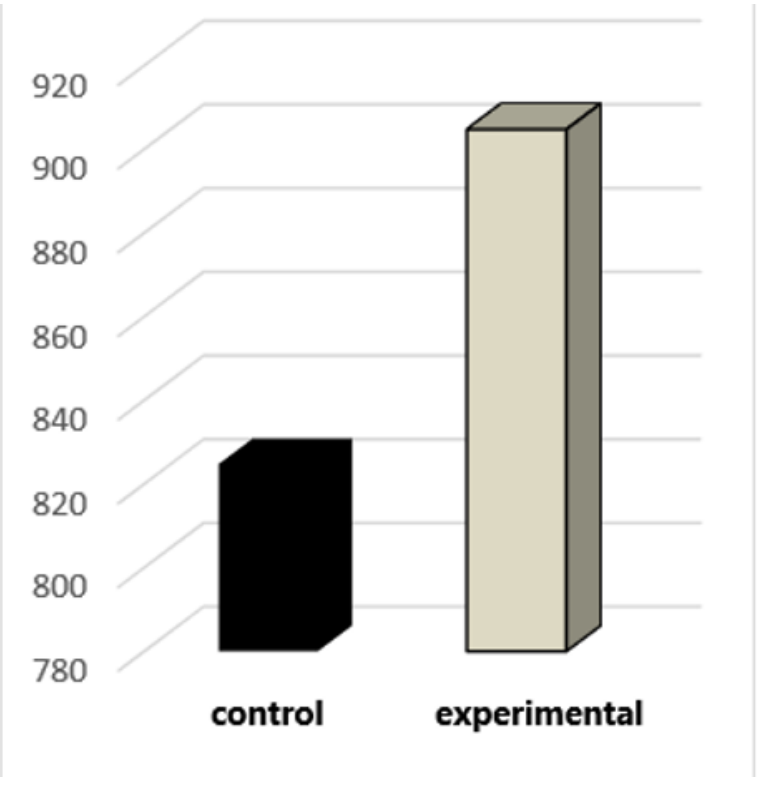

Fig. 3. Average daily goby growth over the period of experience, $g$

Table 3. Dynamics of animal mass growth

\begin{tabular}{|l|c|c|}
\hline Indicator & Control & Experimental \\
\hline Weight at staging, kg & $368.7 \pm 5.4$ & $368.3 \pm 5.2$ \\
\hline $\begin{array}{l}\text { Weight when } \\
\text { removed, kg }\end{array}$ & $430.6 \pm 4.8$ & $436.1 \pm 4.6$ \\
\hline Gross gain, kg & $61.9 \pm 1.7$ & $67.8 \pm 1.6^{*}$ \\
\hline $\begin{array}{l}\text { Average daily } \\
\text { increase, g }\end{array}$ & $824.7 \pm 22.9$ & $904.8 \pm 22.1^{*}$ \\
\hline
\end{tabular}

The difference is true for $\mathrm{P} ; *<0.05$

\section{Conclusion}

On the basis of the carried out researches it is possible to conclude that inclusion in a diet of bulls on fattening of linseed cake in a combination to "protected" choline favourably affected a course of fermentative and microbial processes in a rumen and productivity of animals.

\section{References}

1. V.N. Romanov, N.V. Bogolubova, G.V. Ivanova, V.A. Deviatkin, Physiological basis and methods for reducing the negative effects of technological stress in ruminants in Collection of scientific theses "Adaptation and formation of physiological functions in animals" 131-134 (MBA, Moscow, 2010)

2. C. W. Forsberg, K.-J. Cheng, Molecular strategies to optimize forage and cereal digestion by ruminants In: D. D. Bills and S.-D. Kung, Eds. Biotechnology and Nutrition 107-147 (Butterworth Heinmann, Stoneham, UK, 1992)

3. V. Kulikova, Treatment with shungitis (Tsentrpoligraph, Moscow, 2006)
4. G. Yu. Laptev, S. V. Poluliashnaya, V.N. Romanov, Effectiveness of use of cellobacterin in the diets of dairy cows Efficient livestock 2, 25 (2009)

5. N.V.Bogolyubova, V.V. Zaytsev, S.A. Shalamova, Methods Of Regulating Physiological And Biochemical Processes And Improving Performance Of Dairy Cows Summer Period Research J. of Pharmaceutical, Biological and Chemical Sciences 9(4), 1390 (July-August 2018)

6. N.V.Bogolyubova, V.V. Zaytsev, S.A. Shalamova, Methods Of Regulating Physiological And Biochemical Processes And Improving Performance Of Dairy Cows Summer Period Research J. of Pharmaceutical, Biological and Chemical Sciences 9(4), 1390 (July-August 2018)

7. N.V. Valenzuela-Grijalva, A. Pinelli-Saavedra, A. Muhlia-Almazan, D. Domínguez-Díaz, H. GonzálezRíos Valenzuela-Grijalva, Dietary inclusion effects of phytochemicals as growth promoters in animal production J. Anim. Sci. Technol. 59, 8 (2017)

8. J. Ward, Probiotic yeast for optimal rumen balance All about feed 25(8), 24-25 (2017)

9. M.K. Mohsen, H.M.A. Gaafar, M.M. Khalafalla, A.A. Shitta, A.M. Yousif, Effect of rumen protected choline supplementation on digestibility, rumen activity and milk yield in lactating Friesian cows Slovak J. Anim. Sci. 44(1), 13-20 (2011)

10. Retrieved from: http://bizorg.su/kormarastitelynogo-proishozhdeniya-r/p202435-lynyanoyzhmyh-dlya-krs.

11. E.M. Poverinova, I.A. Loshkomoynikov, L.V. Burlakova et al., Efficiency of use of flax cake, sunflower, redhead and canola varieties of cabbage crops in fattening bulls Scientific-technical Bulletin of the All-Russian Scientific Research Institute of Oilseeds RAASHN 135, 156-158 (Krasnodar, 2006)

12. G. Jayaprakash, M. Sathiyabarathi, V. Arokia Robert, T.Tamilmani, Rumen-protected choline: A significance effect on dairy cattle nutrition Veterinary World 9 (2016)

13. A.V. Mishurov, N.V. Bogolyubova, V.N. Romanov, Influence of different sources of protein nitrogen in sheep's diets on scar digestion and digestibility of nutrients (in Russian) Sheep, goats, woolen business 4, 40-43 (2018)

14. A.V. Mishurov, N.V. Bogolyubova, V.N. Romanov, Features of digestive and metabolic processes in sheep when using different sources of protein Achievements of science and technology of agroindustrial complex 32(8), 66-70 (2018)

15. L. Pinotti, C. Paltanin, A. Campagnoli, P. Cavassini, V. Dell'Orto, Rumen protected choline supplementation in beef cattle: effect on growth performance Italian J. of Animal Science 8(2), 322324 (2009) DOI: 10.4081/ijas.2009.s2.322. 